\title{
Good Governance
}

\author{
Peter Emerson \\ The de Borda Institute, 36 Ballysillan Road Belfast BT14 7QQ, Northern Ireland \\ Tel. 0044(0)2890711795, 0044(0)7837717979 \\ E-mail address: pemerson@deborda.org
}

\begin{abstract}
In many countries, 'free and fair' parliament elections precede a process of cabinet selection which, in contrast, is often far from transparent. In single party majority rule, the party which wins the election then forms the government, its leader becomes the premier, and he/she then has the power to hire and fire ministers, as it pleases. Where elections result in a number of parties being represented in parliament, none of which has a majority, there invariably follows a very opaque part of the democratic process: inter-party meetings, wherein various parties try to form a majority coalition, with ministries allocated to party functionaries in deals perhaps shady or worse. A third structure relates primarily to conflict zones, all-party power-sharing; in these situations, any negotiations by which a government is formed can be both problematic and protracted. It need not be so. In either a singleparty majority rule, a majority or grand coalition, or a unity government, the parliamentary party or parties concerned could use a transparent voting procedure, a tabular mechanism by which every $\mathrm{mp}$ can vote, not only for those whom they wish to see in government, but also for each nominee's ministerial post. It is called a matrix vote. This article will examine different government structures one-party, two-party and multi-party states; it will examine the assumptions on which democracy is based, with particular regard to the fact that the right of a majority to rule is often interpreted to mean that political decisions can best be resolved by binary votes; it will consider a hypothetical example of the matrix vote; and finally, it will discuss the feasibility of an inclusive, all-party political structure.
\end{abstract}

Keywords: Consensus; all-party power-sharing; Modified Borda Count (mbc); matrix vote

$\begin{array}{llll}\text { Abbreviations } & & \\ & & \\ \text { av } & \text { irv }=\text { stv } & \text { alternative vote } & \\ \text { bc } & \text { Borda count } & & \\ \text { cdu } & \text { Christian Democratic Union } & \text { Germany } & \text { Christlich Demokratische Union } \\ \text { Deutschlands } & & & \\ \text { csu } & \text { Christian Social Union } & \text { Germany } & \text { Christlich-Soziale Union } \\ \text { eisa } & \text { Electoral Institute } & \text { South Africa } & \\ \text { fdp } & \text { Free Democratic Party } & \text { Germany } & \text { Freie Demokratische Partei } \\ \text { fpp } & \text { first-past-the-post } & & \\ \text { gnu } & \text { government of national unity } & & \\ \text { irv } & \text { = av= stv instant run-off voting } & \\ \text { mbc } & \text { modified Borda count } & & \\ \text { mmp } & \text { multi-member proportional } & & \\ \text { nig } & \text { New Ireland Group } & & \\ \text { odm } & \text { Orange Democratic Movement } & \text { Kenya } & \end{array}$




$\begin{array}{lll}\text { pr } & \text { proportional representation } & \\ \text { stv } & =\mathrm{av}=\text { irv single transferable vote } & \\ \text { spd } & \text { Social-democratic Party of Germany } & \text { Sozialdemokratische Partei } \\ \text { Deutschlands } & & \\ \text { trs } & \text { two-round system } & \\ \text { qbs } & \text { quota Borda system }\end{array}$

\section{Terminology}

The matrix vote can be used whenever a group of persons is electing a certain number of individuals to undertake different functions in, as it were, a team. One such scenario is when, at an agm, an association chooses to elect an executive committee consisting of a chairperson, a secretary, a treasurer, and so on. Other settings could see the members of a political party elect its executive, or a parliamentary party elect a (shadow) cabinet, or two or more parties elect a majority coalition government. This article, however, will consider the formation of an all-party coalition. First, a few definitions:

'majority coalition' is a combination of two or more parties which between them hold more than 50 per cent of the seats in parliament;

'grand coalition' is a combination of the two biggest parliamentary parties;

'all-party coalition' is a combination of all the major parties in parliament, with the possible inclusion of any minor parties or even independents;

'power-sharing' is a term which, in this article, refers to an 'all-party' structure;

'partial ballot' in a ballot for $n$ ministerial posts, a partial ballot is one in which the voter has cast at

least one but less than $n$ preferences;

'full ballot' $\quad$ if a voter casts $n$ preferences, he/she will have cast a full ballot;

'full and completed is a ballot in which the voter has not only cast a full slate of $n$ preferences, but has also cast an A for each of these nominees in the matrix;

ballot'

'total' in a matrix vote, the word 'total' relates to all the points cast for the various

candidates;

while...

'sum'

refers to the points awarded to a candidate for one particular ministry. A

candidate's

'total' is therefore the addition of all his/her 'sums'.

The text refers to four political parties, $\mathrm{W}, \mathrm{X}, \mathrm{Y}$ and $\mathrm{Z}$, and to candidates of alternate gender - from Ms. I to Mr. V - who are all members of one or other of these parties, as identified by their subscript: $\mathrm{I}_{\mathrm{W}} \ldots \mathrm{L}_{\mathrm{W}}, \mathrm{M}_{\mathrm{X}} \ldots \mathrm{P}_{\mathrm{X}}, \mathrm{Q}_{\mathrm{Y}} \ldots \mathrm{S}_{\mathrm{Y}}$ and $\mathrm{T}_{\mathrm{Z}} \ldots \mathrm{V}_{\mathrm{Z}}$.

\section{INTRODUCTION}

In many democracies, elections are increasingly transparent. Indeed, in the best contests, details of local counts are posted on the web and anyone, politician or punter, can check both 
local and national tabulations. What happens next, however, the process by which a cabinet of ministers is chosen, is often not so clear. If a single party wins a majority of the seats, it then forms the government; but the appointment of all the individual ministers is far from transparent, dependent as it often is upon the will or whim of the party leader. If no one party has a majority of the parliamentary seats - and this is more likely in jurisdictions which use a proportional representation, (PR), electoral system - the next stage is even more opaque. In rooms no longer full of smoke, parties enter into negotiations, as often as not behind closed doors, until eventually the party leaders concerned decide to form a majority or grand coalition, and agree as to who shall undertake which ministerial responsibility.

A third possibility is likely in times of crisis and/or in post conflict societies, namely, an all-party power-sharing coalition, a government of national unity, (GNU). In these circumstances, negotiations on all the various ministerial appointments can often be tortuous, unless that is, a formula has already been devised.

In all three scenarios - (I) single party rule, (II) majority/grand coalition, and (III) power-sharing - it should be possible to introduce the following more transparent structure by which parliament appoints its executive. The people elect their representatives to the legislative chamber, and then:

(I) from among its own ranks, the members of that single parliamentary party elect their government;

(II) again from among their own ranks, the members of those parliamentary parties forming the majority/grand coalition elect their cabinet; or

(III) the entire parliament elects a GNU.

A number of electoral possibilities exist. For any given executive of, let us say, only six ministerial posts - PM, deputy PM, Finance, Foreign Affairs, Education and Defence, (and it is these six which will be used in a hypothetical test case later on in this text) - the said parliament could elect any one person from the given list of candidates ${ }^{1}$ to fill each of the given posts in turn, in a manner not unlike that which occurs in civil society in many AGMs: the election of a chairperson is followed by that of the secretary, a third ballot for treasurer, and so on, usually on the basis of majority/plurality votes. The obvious disadvantage of this system is that (I) the stronger wing of the party or (II) the stronger party/ies in the coalition or (III) one or other faction in parliament could dominate each and every ministerial appointment. A better approach might be for parliament to elect its team of six ministers, at best by a system of PR, whereupon each of those chosen is then appointed to a portfolio by predetermined order in descending order of popularity. This, however, could lead to the economist taking on Education, while the educationalist gets Defence, or whatever. A third possibility is to let the persons elected choose who does what themselves. But that, of course, could lead to endless squabbles.

So maybe the most transparent procedure would be to allow the relevant parliament to vote in such a way that every MP chooses, in order of preference, not only his/her six candidates, but also the ministerial post in which he/she wants each of these nominees to serve. At its best, the appropriate voting system, the matrix vote, is such that, individually, the most suitable candidate, albeit in the consensus of the given parliament, is appointed to each department; while collectively, the team represents in due proportion (I) all the factions in the ruling party, (II) both or all the parties in the coalition, or (III) the entire parliament.

\footnotetext{
1 The list could consist of all the relevant MPs or, as in France and Tanzania, to name just two examples,
} it could also include some non-parliamentarians. 
With a view to improving the transparency by which newly elected parliaments then form their governments, this article first discusses various democratic structures, from a no- or one-party to a two-party and then a multi-party state. It also examines the assumptions upon which such structures are based: not least, the right of a majority to rule by majority vote, with instances taken from both the developed world and sub-Saharan Africa. Next, via a simple example, it demonstrates how a matrix vote could work in what is probably its most difficult setting, (III), electing a GNU. Finally it asks and tries to answer the question: will it work?

\section{THE DEMOCRATIC 'X'-PARTY STATE}

Electoral systems vary enormously, from single-preference systems like first-past-thepost (FPP) \{as in UK and Kenya\}, via the simpler forms of PR-list, \{the Netherlands and Poland $\}$, via a two-tier system like multi-member proportional (MMP), \{Germany - see below\}, to preferential systems like the alternative vote (AV) \{Australia\} and PR - single transferable vote (PR-STV) \{Ireland\}. Decision-making procedures, in contrast, are all very similar: in theory, they could be anything from the two-option majority vote to the multi-option and preferential Borda and/or Condorcet rules; in practice, however, they are nearly all dichotomous, with decisions in parliaments (and elsewhere, in both business and civil society) invariably taken on the basis of a (simple, weighted, qualified or consociational) majority vote, $^{2}$ that or a number of such binary votes. ${ }^{3}$

A second variable, governance, covers a broad spectrum - or is it a circle? - which ranges from the no-party or one-party state, via the two-party and multi-party version, to the all-party state. This article starts with that which has come to be associated with the AngloSaxon democracies, the English and now British two-party state.

\section{1. The two-party state}

It evolved. In its early days, the English parliament did not have any political parties. Then, however, partly because of the geography of the House of Commons with its two rows of facing benches, but mainly because the members took (and take) decisions by majority vote, the MPs divided into two opposing camps; these became, in time, the Whigs and the Tories. Initially, the latter were in fact nicknames, terms of abuse hurled at each other in a form of mud-slinging that still exists today. The word "whig" was slang for a "money-grabbing Scots Presbyterian' while a "tory" was an 'Irish Papist bandit'. (1)

Years later, in 1884, even though electoral reform was by now in the public domain, the Whigs and Tories got together and, in a debate which 'was shaped throughout by the needs and interests of the party leaders, and settled, symbolically, in a private inter-party conclave,' (2) they adopted FPP.

After each election, the larger of the two parties - larger not necessarily in terms of votes but of the number of parliamentary seats - formed the government. The leader of that party became the premier, and he or she, alone, had the final word on who was to be in cabinet. There was virtually no transparency in this at all. Indeed, when talking about

\footnotetext{
2 The Norwegian parliament has provision for the two-round system (TRS) of voting but it is seldom used - the last occasion was in 1972 - while Finland and Sweden use serial voting when debating amendments.

3 Many countries use multi-option (but not preferential) voting in referendums: New Zealand, for example, held a five-option ballot in 1992, using a form of the two-round system, (TRS).
} 
Margaret Thatcher, Lord Hailsham described the system as an 'elective dictatorship'. She chose the cabinet; if she changed her mind and deemed a minister to be 'wet', she wielded the handbag and re-shuffled. Then, in day-to-day business, her cabinet proposed a piece of legislation. Parliament debated that proposal and took a vote but, because she had a majority in parliament, she was almost bound to win that ballot; in instances of doubt, she cracked the whip. She did indeed dictate and, in varying degree, the same was true for many of her predecessors and successors. The system - majority rule based on majority voting - is called majoritarianism.

It worked, in its own way, when there were just two main parties. Given, however, that the dominance in the UK of the two big parties is on the wane while the fortunes of some other parties are rising, the likelihood of any one single party gaining 50 per cent or more of the seats is now minimal. In the election of May 2010, the Tories got 306 seats, Labour had 258 and the Lib-Dems won 57; so any combination of two of these could have enjoyed a majority in the House of 326 seats. In the next election, given the emergence of the UK Independence Party and the Greens, let alone the Scottish National Party and others, the mathematics of forming a parliamentary majority may become more convoluted.

\section{2. The Multi-Party State}

In many respects, as Maurice Duverger said is his now famous law, the electoral system determines the nature of the political structure. The UK has FPP, an electoral system with an effective threshold of 35 per cent, (3); it therefore acquired the above two-party system. In the Netherlands, the effective threshold of their form of PR-list is tiny, 0.67, so the Dutch have, roughly, a five-party system. In Poland, the electoral system is similar and so there too, despite having a five per cent minimum, there is five-party system. The German system, which also uses this minimum, is MMP, which is part FPP and part PR-list, so Germany has a two-big-plus-two or three-small party structure.

The belief in the right of a majority to rule is very strong, so if and when no one single party does have a majority, which is nearly always in the last three countries, deals are made. This usually means that the largest party teams up with a smaller one. This in turn means that the smaller partner often has far more influence than is its due. In 2011, for example, the Dutch formed a minority administration with the support of, but without giving ministerial posts to, the right-wing Freedom Party.

In Ireland in 1982, one sole MP - Tony Gregory $\mathrm{TD}^{4}$ - became the "king-maker", and kept the then premier, Charlie Haughey, in power... at a price! Before asking whether it is right that governance should be so vulnerable, let us examine two mathematical conundrums, one in Germany, the other in India.

\subsubsection{Germany}

The 2005 elections was almost a dead heat: the Christian Democratic Union/Christian Social Union, (CDU/CSU) won 226 seats and the Social-Democratic Party, (SPD) 222, while the Free Democratic Party, (FDP), The Left and the Green Party, got 61, 54 and 51 seats respectively. There were thus seven possibilities, all of which could have commanded a majority of 308: either a grand coalition of the two big parties, or a majority coalition of either of the big plus any two of the three small. Each of these combinations was different and yet, for the majoritarian, each was totally democratic.

$4 \quad$ TD, Teachta Dála, member of Dáil Éireann, the Irish Parliament. 
The discussions which followed that transparent election were more complex than, but just as secretive as, those in London in 2010; eventually it was decided to form a grand coalition of the CDU/CSU and SPD.

In 2009, the CDU/CSU reverted to a majority coalition with the FDP but, in the wake of the 2013 elections, after five weeks of negotiations which culminated in an all-night session not the most transparent of proceedings - the CDU/CSU joined up with the SPD in another grand coalition.

\subsection{India}

In the wake of the 2009 elections, the 543 seats of the parliament in Delhi were shared by over 40 different political parties. One coalition of 11 parties had 262 seats; another of eight had 159; the so-called Third Front of 12 parties had 79; the Fourth front of three had 27; while seven parties had just one seat each, as did nine independents. Given that Indian politics can be rather fluid, with parties joining different coalitions before, during and after elections, the number of different combinations and permutations - and in a majoritarian interpretation, each of them would have again been totally democratic - boggles the mind.

\section{3. The One-Party State}

In a majoritarian milieu, then, multi-party parliaments become increasingly problematic. Perhaps, then, it is time to go round the circle (or spectrum) in the opposite direction, from the two-party state to the one-party state.

On gaining independence, many countries are filled with a democratic idealism. This was certainly true in the New World. So while some one-party states are horrible - the Soviet Union as was, the Democratic Republic of North Korea as is - others have been of a different ilk. This text starts with a good one.

\subsection{The USA}

Among the ideals which nurtured the founding fathers was, inter alia, a sometimes bitter opposition to the two-party structure of governance. George Washington, for one, complained in his farewell address of 1796 that 'the alternate domination of one faction over another... has perpetrated the most horrid enormities [and] is itself a frightful despotism.' They therefore devised a different and very inclusive electoral system: the winner became the president but the runner-up became the vice- president. They also devised various formulas for the proportional representation of persons and states in the elected chamber. They did not, however, reform the decision-making system: they still used the majority vote, and it was this, rather more than Duverger's Law, which determined the eventual two-party nature of US politics.

The one-party idealism did not last for long, for the politics of President Andrew Jackson, 1828-32, were based on party political patronage; from henceforth, the winning party was expected to enjoy the spoils of office. The US has been a two-party system ever since, much to the bemusement of many: 'Today the Republicans stand at the helm... tomorrow it will be the Democrats or the Republicans once again. There is no particular difference,' (4). Similarly, in the UK, there was very little to distinguish between the policies of John Major and Tony Blair. In a two-party structure, both parties tend, at times, and certainly at some election times, to become rather similar, to woo 'middle America' or 'middle England'. Indeed, under FPP, a bad two-party structure is sometimes not much better than a good oneparty state. 


\subsubsection{Russia}

When the Soviet Union decided, in 1988, to become a democracy, many experts went to Moscow to advise Mikhail Gorbachev of the advantages of a western polity: majority rule by majority vote. Alas, Mikhail Sergeyevich did not speak English, so everything had to be done through translation; but the Russian word for majoritarianism is bolshevism. ${ }^{5}$ (To save embarrassment, a new word has now been devised: majoritarnost.). The 1989 elections were duly held in what was still a one-party state. In Congress, decisions were taken by majority vote. It therefore split into two opposing factions, each led, as it happens, by a Nobel laureate: Mikhail Gorbachev and Andrei Sakharov. Russia now uses a PR-list system and has become, like others in Africa, a one-party-dominant state.

Given the history of Eastern Europe, it is hardly surprising that Vaclav Havel and others became 'rather sceptical about the very principle of mass political parties. I'm not opposed to the solidarity of various interest groups of like-minded people. It's just that I'm against anything that... rewards anyone with privileges for devotion to a particular power-orientated group.' (5)

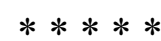

And so to Africa. When the colonial powers 'gave' independence to their former colonies, they tended to ignore any traditional forms of governance and imposed their own European norms instead. Throughout sub-Saharan Africa, however, in the old days, 'if someone is quarrelling with someone else, then the court convened beneath the tree... will set itself the sole task of ending the conflict... while granting to each that he is in the right.' (6) In a nutshell, 'Asking yes-or-no questions is very unAfrican, ${ }^{, 6}$ and 'Majority rule was a foreign notion.' (7) Rather, to cite a case from Malawi, elders would "sit under the big tree" and talk until they came to an agreement; the word in Swahiliphone Africa is baraza; in Frenchspeaking countries, it is palabre; and in Rwanda they say gacaca.

On gaining independence, many countries adopted a one-party structure. Again, this tour d'horizon starts with a good example.

\subsubsection{Tanzania}

Even before independence, Julius Nyerere argued for a one-party system: '...it could hardly be expected that a united country should... voluntarily divide itself into opposing political groups just for the sake of conforming to what I have called the "Anglo-Saxon form of democracy",' (8). So, in 1961, Tanzania became a one-party state. If success is measured in terms of peace, it was a very successful policy. Indeed, on a return visit in 2003, the present author considered the country to be post-tribal. Admittedly, it now enjoys multi-party elections, and has done so since 1994; it is a presidential system, in which the president

\footnotetext{
$5 \quad$ It comes from the Russian word for majority, bolshinstvo; and the Bolshevik Party was established, in London, when the All-Russian Congress of Social Democrats took a majority vote. The winners - by two votes with three abstentions - became the Bolsheviks. And hence, too, the Mensheviks, those of the minority or menshinstvo.
}

6 This was a comment from the floor at a press conference held in Kigali in 2003 to launch the results of a survey carried out on behalf of Rwanda's National Unity and Reconciliation Commission. The author was in attendance. 
appoints the cabinet, not all of whom must be elected MPs. The system, has evolved into a one-party-dominant state.

\subsubsection{Kenya}

Today's Kenya is most definitely not post-tribal. Unlike Tanzania which also has a multitude of different tribes, Kenyan demographics fall into two (multi-tribal) ethnic groups: the Bantu, of which the largest tribe is the Kikuyu, and the Nilotic, who are dominated by the Luo. Was it wise to bequeath a two-party system of majoritarianism - FPP in elections and majority votes in parliament - to such a potentially divided land?

In 1964, the year of independence, the first president Jomo Kenyatta said that Kenya would soon become a one-party state, and the split with his former colleague, a Luo, Oginga Odinga, was rapid. By the '70s, many Kenyans were content to allow the old man, Mzee, to die, but the question of his succession raised the prospect of another Kikuyu, or would it be a Luo, or maybe the representative of a minority tribe? The proceedings were far from democratic. Of likely contenders, some were murdered: Tom Mboya, (Luo), in 1969 and J M Kariuki, (Kikuyu), in 1974 . $^{7}$

When eventually Kenyatta passed away, the presidency went to Arap Moi, a member of the Kalenjin minority. He introduced multi-party democracy in 1991 and, in 2002, he himself was replaced, democratically and in large part peacefully, by Mwai Kibaki, who thus became Kenya's second Kikuyu president. Five years later, the situation was very different. The electoral system was still the (very unAfrican) FPP, but while Raila Odinga's Orange Democratic Movement, (ODM), won most of the seats in parliament, Kibaki won the presidential contest. Foul play was suspected, rumours spread, and Kenya exploded into violence. As a result, a power-sharing administration was appointed (see below), and Kenya has moved from a one-party to a two/multi-party to an all-party-state.

\subsubsection{Uganda}

After only four years of democracy, a newly independent Uganda was ruled first by Milton Obote in 1966 and then by Idi Amin in 1971. After one of the most successful regime changes in modern history, when Tanzania's Nyerere forced Amin into exile, Obote returned to power, but because of the winner-takes-all arrangement on which the 1980 elections had been organised, only the Uganda Peoples Congress was represented in cabinet. This further period of instability lasted until 1986, when Yoweri Museveni took over.

One of his first steps was to ban all political parties, because 'they created hysteria by setting people against each other, polarising them along the lines of their tribal or religious identity,' (9). Instead, an organisation called the National Resistance Movement was to be the basis of a no-party state - or was it a one-party state? - but at least Uganda was now at peace.

In a system of governance whereby the African country adopts one or other particular measure on the basis that a Western country pays for it, Uganda returned to multi-party elections via a referendum in 2005. It too, today, is a one-party-dominant state.

\section{4. The All-Party State}

The frailties of Kenya politics are sometimes blamed onto those of African birth. It should therefore be pointed out that J M Kariuki's death was also with the connivance of a European, one Patrick Shaw, with whom the author was acquainted. 
To complete the circle, consideration shall now be given to the all-party state. If every MP were to be an independent, this could be the same as a no-party state; or, if all were united in purpose, a one-party state. The circle is complete.

When the era of apartheid came to an end, there were very few examples in the world of an all-party state. Lebanon had devised a system of power-sharing in 1943, Switzerland had adopted a combined presidency in 1959, and apart from a few non-party jurisdictions as in Nunavut in Canada, that was about it. To a large extent, therefore, South Africa and other post-conflict societies have had to devise their own systems of governance, with varying degrees of transparency.

All-party power-sharing relates to two aspects: the first concerns appointments to various political chambers or specific offices; the second relates to decision-making in those elected bodies.

\subsection{Lebanon}

The Taif Agreement initiated a form of power-sharing such that the president was a Maronite, the prime minister a Sunni and the speaker a Shia. Decision-making, however, was still by majority vote. Perhaps the most interesting part of this agreement concerned the electoral system: a form of multiple FPP. To take a hypothetical example, if a constituency were to consist of 33 per cent Maronite and 66 per cent Sunni, there would be three simultaneous FPP elections for one Maronite and two Sunni MPs. Any party wishing to stand had to nominate three candidates in the same confessional ratio, and every voter had to cast three votes in the same way. Thus, in theory (though not quite in practice), sectarianism was removed from politics. ${ }^{8}$

\subsection{Switzerland}

In 1959, Switzerland introduced a Zauberformel or magic formula for the appointment of an all-party collective presidency, the Swiss Federal Council. The seven-person team was comprised of members from the four largest parties in parliament on the ratio of 2:2:2:1 and so far, the 'magic' has worked, though the formula has now been changed for five parties to $2: 2: 1: 1: 1$.

A further aspect of Swiss power-sharing is the fact that its political system is very decentralised. A lot of power is devolved to the cantons, and yet more to the citizenry via the mechanism of citizens' initiatives.

\subsubsection{South Africa}

In drawing up a transitional constitution, it was agreed that 'a party that held a minimum of 80 seats in the 400-member National Assembly should be entitled to designate an executive deputy president... and that a party holding at least 20 seats should be entitled to be allocated one or more Cabinet portfolios in [due] proportion,' (10). The numbers, then, were transparent; alas, the procedure by which a particular portfolio was to be allocated was not so well defined.

\footnotetext{
$8 \quad$ Dagestan devised another FPP variation: all the candidates in one constituency had to be Sunni, all in another were Shia, etc., so again, sectarian differences between candidates were, in theory, irrelevant. Alas, in 2007, that system was replaced by a form of PR-list.

Papua New Guinea has also tried to diffuse sectarianism in elections. They use AV with the proviso that, for a vote to be valid, it must contain at least three preferences. In effect, this usually means that the voter must cross the tribal divide at least twice.
} 
With regard to decision-making, the African National Congress agreed to support power-sharing, provided the minority parties did not have a veto. It was also agreed that, after five years, the GNU would become a simple majority-rule government: ${ }^{9}$ so South Africa moved from an all-party to a one-party-dominant state.

\subsection{Bosnia}

The Dayton Agreement brought an end to the war in Bosnia in 1995, but it was very sectarian. The country itself was divided into two sectarian 'entities', Republika Srpska and the Federation; the former is largely Orthodox Slav; the latter is shared mainly by Catholic Slavs and Muslim Slavs. In addition, cantons were introduced into the Federation, largely to cater for the religious differences between the two faith groups concerned.

A three-sided version of consociationalism (see below) had been tried prior to the war but, 'In its eighteen month-long existence, the Bosnian parliament failed to pass a single law,' (11). The situation has not improved very much since, despite the power-sharing arrangements - the three-person presidency, for instance, must consist of one of each religion - and, all too often, in the elected chamber, the veto is applied by one or other of the three groupings, resulting in political impasse.

\section{4. 5. Northern Ireland}

In accordance with the 1998 Belfast Agreement, appointments to the Executive are made by a d'Hondt interpretation of the number of seats held by the main parties in the Assembly. This is all very transparent. On the down side, however, it means that members of the smaller parties can neither aspire to office nor play any part in the selection of the executive; instead, all power rests with the party leaders of the big parties.

Decision-making is based on the Belgian model of consociationalism. All the Members of the Legislative Assembly first designate themselves as 'unionist', 'nationalist' or 'other'. Then, in debate, a 'key' policy can only be adopted if it receives majority support from both the 'unionists' and the 'nationalists'. This means any 'others' have less influence in the vote; and secondly, that both unionists and nationalists have the veto.

Both the appointment of ministers and decision-making are therefore very sectarian. When combined with the fact that any referendum on the future of the province is to be a sectarian contest between only two options - in effect, do you want to be British or Irish? the Belfast Agreement has caused 'sectarianism [to be] more overt in the post-Agreement era,' (12).

$* * * * *$

All of the above power-sharing formulas - in Lebanon, Bosnia and NI - have tended to institutionalise sectarianism. Admittedly, laying down one or other formula for the appointment of ministers has allowed that part of a power-sharing agreement to be reasonably well-handled. Executive appointments elsewhere have not been so readily resolved.

\subsection{Kenya}

As noted above, para 2.3.4, the 2007 elections led to terrible violence. As a result, a system of power-sharing - which could be described as an opposite of majority rule - was then advocated by those who had first bequeathed the latter polity. There was no formula,

9 Sadly, in his autobiography, Nelson Mandela makes no further comment on this un African polity, despite its variance to his earlier statement \{see quotation in para 2.3.2\}. 
however, so reliance was made on a purely verbal approach, which was facilitated by outside mediation under the guidance of Kofi Annan. Eventually, after 70 terrible days, on $18^{\text {th }}$ March 2008, a coalition of the two biggest parties - Kibaki's Party of National Unity and Odinga's ODM - was agreed to. Decision-making, however, was still to be by majority vote.

\subsection{A World Record}

Of those other countries which have tried to form a government by negotiations only, Iraq took 249 days, but the record goes to Belgium which took 541.

$* * * * *$

On the basis of the above, it is submitted that a recognised formula by which a parliamentary electorate - the MPs in (I) a single party, (II) the partners of a coalition, or (III) an entire parliament - could elect an executive, would make democracy more transparent. The only ethno-colour blind methodology so far devised is the matrix vote, and, in theory at least, it could be used in even the most fraught of post-conflict scenarios.

\section{DEMOCRATIC ASSUMPTIONS}

Consideration must first be given to some of the principles upon which democracy is based. The first is majority rule, a dogma that few would question. What should be examined, however, is that which many regard as a logical consequence, the assumption that democracy works on the basis of a decision by the majority. This implies that every problem is dichotomous, and that every decision has to be taken on the basis of a binary choice, or a series of such (simple or weighted) majority votes.

\section{1. Majority Voting}

In 1991, the EU's Badinter Commission recommended that problems in the Balkans should be resolved by plebiscites. As a result, there was a plethora of them, and Sarajevo's now legendary newspaper, Oslobodjenje, later reflected that 'all the wars in the former Yugoslavia started with a referendum,' (op. cit., 7.2.1999). Despite this and other tragedies, a belief in majority voting remains, not least because 'the theory of voting... appears to be wholly unknown to anyone concerned with its practical applications,' (13). Nothing was learnt from the Balkans; a few warned that a similar policy in South Sudan 'would open a Pandora's box in the whole of Sudan,' (14), but the practice of self-determination via a majority vote - in a word, Balkanisation - has now been exported to Africa.

This is partly because, 'there is a surprisingly strong and persistent tendency in political science to equate democracy solely with majoritarian democracy and to fail to recognize consensus democracy as an alternative and equally legitimate type,' (15). Yet even Lijphart is here only comparing simple majority rule with consociationalism; which is also dichotomous. Most contentious debates in a plural democracy, however, as it were by definition, involve a plurality of possible options - if, that is, the question has been asked correctly. ${ }^{10}$ In which case, majority voting may be quite inappropriate. When there are indeed more than two options on the table, an individual voter or elected representative can only express his/her

\footnotetext{
10 In the 1992 referendum in Bosnia, for example, the question need not have been - in paraphrase "Independence, yes or no?" Rather, it could have offered the voter a range of options, which did already exist in political negotiations, from independence via confederation to status quo, and so on.
} 
views in a precise manner if he/she is allowed a free, unwhipped, preferential vote. In which case, the best way to identify the collective will of the said electorate is by taking all preferences cast into account, and this in turn means that reliance has to be placed on either the Condorcet rule and/or the Borda rule.

Alas, western diplomacy still relies on majoritarianism. The worst consequence was in Rwanda where, in 1994, the Interahamwe launched their genocide with the slogan, "rubanda nyamwinshi", we are the majority, the bolsheviks. (16). ${ }^{11}$

\section{2. Party Politics}

Largely because of the ubiquitous use of the majority vote, it is often assumed that democracy should involve political parties, each of which competes for power in an elected chamber. Yet in theory, in many countries, it could happen that all the elected MPs were independent members. Would the parliament be any less democratic for that? Maybe, as Vaclav Havel implied, the fault lies in the political patronage which has come to be so much a part of the party political system, i.e., in the power which is given to the party leaders.

Likewise, it is usually assumed that majority rule will prevail except, perhaps, in times of crisis - during WWII for example, Britain enjoyed a coalition government. Furthermore, in recent years, there have been a number of calls, in Greece and Ireland to name but two, for a GNU to tackle the economic crisis; and even more such calls in crisis zones, from Afghanistan to Fiji to Zimbabwe.

It must also be pointed out, as outlined above \{para 2.2\} in the cases of the Netherlands and Ireland, that a majoritarian democracy can be a hostage to the political ambitions of minority parties or even of a lone independent MP who, if successful, gains a measure of power which is far in excess of his/her proportional due; secondly, as in Germany or India, \{paras 2.2.1 and 2.2.2\}, any belief in majority rule can and sometimes does lead to much confusion.

\section{3. A Consociational or a Consensual Polity?}

If, as suggested above, majority voting is inadequate, there is little or no justification for a democratic structure in which decisions on contentious issues are taken by this methodology. The right of a majority to rule may be fair. But that does not mean that majority opinions must be determined by an Orwellian majority vote, or that these judgements actually represent the will of the given majority. Indeed, on many occasions, the outcome of such a binary ballot represents not the will of the many, the majority, but rather, the will of a tiny minority, the few who actually set the question. Little wonder, then, that majority voting has been the chosen instrument of so many dictators: Napoleon, Lenin, Mussolini, Hitler, Gaddafi and Khomeini, to name but a few, (17).

Given that in many situations, a majority will try to ride roughshod over any minority interests, it is suggested that the best way to ensure that all minorities can participate in a democracy is by using a decision-making process via which the very words 'majority' and 'minority' become obsolescent. Democracy, after all, is for everybody. Decision-making should be the means by which all can influence that which then becomes the confluence; at best, a decision-making voting procedure should be that which identifies the option which is the most popular, i.e., which has the highest average preference - and an average, of course,

11 To try and overcome the legacy of that massacre, the Rwandan government has re-introduced the word gacaca, \{para 2.3.2\}, little Truth and Reconciliation Commissions. 
involves everybody, not just a majority. The procedure is called a modified Borda count, $(\mathrm{MBC})-$ see paras 4.3.2 and 5\}.

In other words, everyone (or every elected representative) has the responsibility to come to an accommodation with their fellow citizens (or parliamentarians). Power-sharing rather than majority rule should be the norm. But first, let us turn our attention to that voting mechanism by which (I) a single party, (II) two or more parties, or best of all, (III), a parliament in its entirety could elect an executive in an inclusive and transparent methodology.

\section{THE MATRIX VOTE}

In the matrix vote, there is just the one ballot paper, a simple example of which is shown in Figure 1. The resulting voters' profile is then subject to two counts. A quota Borda system, (QBS), election, \{para 4.3.1\}, based on the preferences cast in the 'Cabinet' column, shown here in tint, identifies the six most popular MPs; they shall form the cabinet. In the second count, an MBC election based on the candidates' sums in the matrix determines who shall serve in which ministry.

Let us assume that, in a parliament of 30 MPs, parties $\mathbf{W}, \mathbf{X}, \mathbf{Y}$ and $\mathbf{Z}$ have 10, 10, 5 and 5 MPs respectively, and while $\mathbf{W}$ and $\mathbf{Z}$ are fairly close in political orientation, so too of an opposite hue are $\mathbf{X}$ and $\mathbf{Y}$. Let us further assume that it has been decided to elect a government of just six ministers, as listed in Figure 1.

Figure 1. The Ballot Paper.

\begin{tabular}{|c|c|c|c|c|c|c|c|}
\hline \multirow{2}{*}{\multicolumn{2}{|c|}{$\begin{array}{c}\text { THE CABINET } \\
\text { Names of } \\
\text { candidates } \\
\text { in order of preference }\end{array}$}} & \multicolumn{6}{|c|}{$\begin{array}{c}\text { THE } \\
\text { PORTFOLIOS }\end{array}$} \\
\hline & & $\sum_{i}$ & 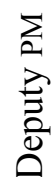 & 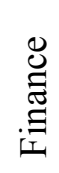 & 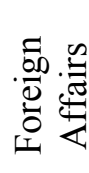 & 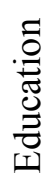 & 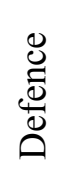 \\
\hline $1^{\text {st }}$ & & & & & & & \\
\hline $2^{\text {nd }}$ & & & & & & & \\
\hline $3^{\text {rd }}$ & & & & & & & \\
\hline $4^{\text {th }}$ & & & & & & & \\
\hline $5^{\text {th }}$ & & & & & & & \\
\hline $6^{\text {th }}$ & & & & & & & \\
\hline
\end{tabular}

Given that the matrix vote is a form of PR, each party will doubtless consider its chances and endeavour to win as many seats as possible. $\mathbf{W}, \mathbf{X}, \mathbf{Y}$ and $\mathbf{Z}$ can therefore each hope to win 2, 2, 1 and 1 ministerial posts, with the possibility of gaining one extra seat (albeit at another party's expense), if it can get sufficient cross-party support. Now the quota element of QBS, as in PR-STV, incentivises parties to nominate only as many candidates as they can realistically expect to win; while both the MBC and QBS encourage voters to submit full ballots (see para 5). In a matrix vote, therefore, participants' vested interests lie in voting across the 
party/sectarian divides. This, it is suggested, is a pre-requisite of an effective power-sharing polity.

In theory, every MP can stand for any one of the six ministries, ${ }^{12}$ but $\mathbf{W}, \mathbf{X}, \mathbf{Y}$ and $\mathbf{Z}$ will probably promote just 2, 2, 1 and 1 candidates, or at most 3, 3, 2 and 2. Let us assume the latter scenario (see para 4.5). Doubtless, Party W will want the post of PM, but so too might party $\mathbf{X}$. Doubtless too, both $\mathbf{W}$ and $\mathbf{X}$ will want their party leaders, $\mathbf{I}_{\mathbf{W}}$ and $\mathbf{O}_{\mathbf{X}}$, to get this premiership or at least their next best postings, finance or foreign affairs respectively. The parties' probable priorities, then, as in Figure 2, are shown in darker tint.

Figure 2. Political Ambitions.

\begin{tabular}{|c|c|c|c|c|c|c|}
\hline PARTY & $\sum_{i}$ & 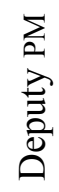 & 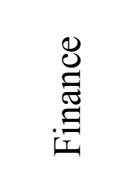 & 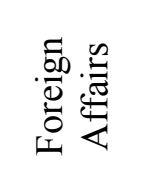 & 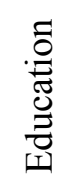 & $\frac{\ddot{U}}{\stackrel{0}{0}}$ \\
\hline $\mathbf{W}$ & $\mathbf{I}_{\mathbf{W}}$ & $\mathbf{J}_{\mathbf{W}}$ & $\begin{array}{c}\left(\mathbf{I}_{\mathbf{W}} \text { or }\right) \\
\mathbf{K}_{\mathbf{W}}\end{array}$ & & $\mathbf{K}_{\mathbf{w}}$ & \\
\hline $\mathbf{X}$ & $\mathbf{M}_{\mathbf{X}}$ & $\mathbf{N}_{\mathbf{X}}$ & & $\begin{array}{c}\left(\mathbf{M}_{\mathbf{X}} \text { or }\right) \\
\mathbf{O}_{\mathbf{X}}\end{array}$ & & $\mathbf{O}_{\mathbf{X}}$ \\
\hline $\mathbf{Y}$ & & & $\mathbf{Q}_{\mathbf{Y}}$ & & $\mathbf{Q}_{\mathbf{Y}}$ & \\
\hline $\mathbf{Z}$ & & & $\mathbf{T}_{\mathbf{Z}}$ & & & $\mathbf{T}_{\mathbf{Z}}$ \\
\hline
\end{tabular}

\section{1. The Candidates}

Party $\mathbf{W}$ 's nominees are $\mathbf{I}_{\mathbf{W}}, \mathbf{J}_{\mathbf{W}}$, and $\mathbf{K}_{\mathbf{W}}$, for the posts of PM, Deputy PM, and Finance respectively; and if $\mathbf{I}_{\mathbf{W}}$ does not win the premiership, it is hoped she will take on Finance, in which case $\mathbf{K}_{\mathbf{W}}$ (shown in a lighter tint) will take on Education. A fourth MP, $\mathbf{L}_{\mathbf{W}}$, is also a possible nominee and his expertise is Foreign Affairs, but Party $\mathbf{W}$ does not think he will win this portfolio.

$\mathbf{X}$ 's main nominee for the premiership is $\mathbf{M}_{\mathbf{X}}$, who has a background in Foreign Affairs. With support coming from both $\mathbf{X}$ and $\mathbf{Y}$ MPs, she has a good chance of winning the top job (as too does $\mathbf{I}_{\mathbf{W}}$ of course). $\mathbf{N}_{\mathbf{X}}$ is going for the post of Deputy PM and $\mathbf{O}_{\mathbf{X}}$ for Foreign Affairs (or Defence). Party $\mathbf{X}$ 's fourth nominee is $\mathbf{P}_{\mathbf{X}}$ for the post of Finance, but his chances are considered to be minimal.

$\mathbf{Y}$ has two nominess $-\mathbf{Q}_{\mathbf{Y}}$ and $\mathbf{R}_{\mathbf{Y}}-$ but all hopes are being put on $\mathbf{Q}_{\mathbf{Y}}$ for the Education ministry or Finance.

$\mathbf{Z}$ also has only two nominees $-\mathbf{T}_{\mathbf{Z}}$ and $\mathbf{U}_{\mathbf{Z}}$ - with the main one, $\mathbf{T}_{\mathbf{Z}}$, going first for Defence or again Finance.

In all, then, Parties $\mathbf{W}$ and $\mathbf{Z}$ are hoping for the posts of PM, Deputy PM, Finance, Defence, and at a long shot, Education. While $\mathbf{X}$ and $\mathbf{Y}$ are concentrating their efforts on PM, Deputy PM, Foreign Affairs and Education, and an equally long shot at Defence.

\footnotetext{
12 An MP may opt out of standing for any particular ministry, if they so wish. It may also be prudent to
} suggest that an MP who has already served, say, two terms should not be eligible for re-election. 


\section{2. The Vote}

In a power-sharing administration, votes could be free. It is nevertheless anticipated that party whips will try to get their MPs to vote according to a certain pattern and that most MPs will comply.

As implied in Figure 1, the ballot paper asks the voter to choose, in order of preference, (up to) six names from the official list of candidates. Having entered their names in the 'Cabinet' column, (shown in Table 1 in tint), the voter then indicates an ' $A$ ' for the ministerial post in which he/she would most like his/her nominee to serve. He may also indicate a ' $\mathrm{B}$ ' (and a ' $\mathrm{C}$ ') for alternative departments, just in case the said candidate is successfully elected to the cabinet but the 'A' post indicated is already filled. \{See 4.3.2).\} For a vote to be valid, the voter must indicate at least a first preference in the 'Cabinet' column. A full ballot will consist of six different names. While a full and completed vote should show six names in the 'Cabinet' column and, in the matrix itself, an ' $A$ ' for the most desired post for each of these six nominees. The final ballot should thus contain one ' $A$ ' in each column, and one in each row (as shown in tint in Figure 3 etc.).

If Parties $\mathbf{W}$ and $\mathbf{Z}$ co-operate, then, with but a few slight differences over particular appointments, Z's MPs will support W's nominees and vice versa. Thus the completed ballot of W's MPs might be as shown in Figure 3 although there is one rebel, $\mathbf{L}_{\mathbf{W}}$, who cannot resist voting for himself, as in Figure 3a. Similarly, the $\mathbf{Z}$ MPs might cast a Figure 6 type ballot. Parties $\mathbf{X}$ and $\mathbf{Y}$ have also been in negotiations, agreeing with almost everything, so their MPs might well vote as in Figures 4 and 5 respectively - again, but for one rebel: this one, $\mathbf{P}_{\mathbf{X}}$, votes as shown in Figure 4a.

Figure 3. Nine Party W MP's Completed Ballot Paper.

\begin{tabular}{|c|c|c|c|c|c|c|c|}
\hline \multirow{2}{*}{\multicolumn{2}{|c|}{$\begin{array}{c}\text { THE CABINET } \\
\text { Names of } \\
\text { candidates } \\
\text { in order of preference }\end{array}$}} & \multicolumn{6}{|c|}{$\begin{array}{c}\text { THE } \\
\text { PORTFOLIOS }\end{array}$} \\
\hline & & \multirow{2}{*}{$\begin{array}{l}\sum \\
A\end{array}$} & \multirow{2}{*}{ 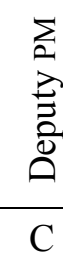 } & \multirow{2}{*}{ 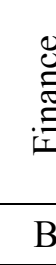 } & \multirow[t]{2}{*}{ 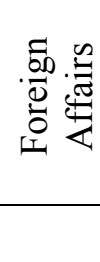 } & \multirow[t]{2}{*}{ 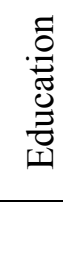 } & \multirow[t]{2}{*}{ 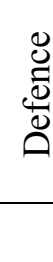 } \\
\hline $1^{\mathrm{st}}$ & $\mathbf{I}_{\mathbf{W}}$ & & & & & & \\
\hline $2^{\text {nd }}$ & $\mathbf{J}_{\mathbf{W}}$ & & A & & $\mathrm{C}$ & & B \\
\hline $3^{\text {rd }}$ & $\mathbf{T}_{\mathbf{Z}}$ & & & B & & & A \\
\hline $4^{\text {th }}$ & $\mathbf{K}_{\mathbf{W}}$ & & & A & & B & \\
\hline $5^{\text {th }}$ & $\mathbf{S}_{\mathbf{Y}}$ & & & & & A & \\
\hline $6^{\text {th }}$ & $\mathbf{P}_{\mathbf{X}}$ & & & & A & & \\
\hline
\end{tabular}


Figure 3a. The rebel Party W MP, $\mathrm{L}_{\mathrm{W}}$ 's Completed Ballot Paper.

\begin{tabular}{|c|c|c|c|c|c|c|c|}
\hline \multirow{2}{*}{\multicolumn{2}{|c|}{$\begin{array}{c}\text { THE CABINET } \\
\text { Names of } \\
\text { candidates } \\
\text { in order of preference }\end{array}$}} & \multicolumn{6}{|c|}{$\begin{array}{c}\text { THE } \\
\text { PORTFOLIOS }\end{array}$} \\
\hline & & \multirow[t]{2}{*}{$\sum$} & \multirow[t]{2}{*}{ 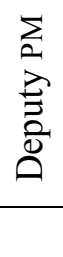 } & \multirow[t]{2}{*}{$\begin{array}{l}\mathscr{\Xi} \\
\text { E్ } \\
\text { : }\end{array}$} & \multirow{2}{*}{ 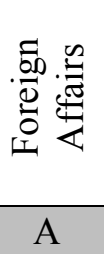 } & \multirow[t]{2}{*}{ 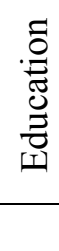 } & \multirow[t]{2}{*}{ 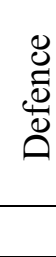 } \\
\hline $1^{\mathrm{st}}$ & $\mathbf{L}_{\mathbf{W}}$ & & & & & & \\
\hline $2^{\text {nd }}$ & $\mathbf{I}_{\mathbf{W}}$ & A & $\mathrm{C}$ & $\mathrm{B}$ & & & \\
\hline $3^{\text {rd }}$ & $\mathbf{J}_{\mathbf{W}}$ & & & & & & A \\
\hline $4^{\text {th }}$ & $\mathbf{T}_{\mathbf{Z}}$ & & $\mathrm{A}$ & & & & \\
\hline $5^{\text {th }}$ & $\mathbf{K}_{\mathbf{W}}$ & & & & & $\mathrm{A}$ & \\
\hline $6^{\text {th }}$ & $\mathbf{P}_{\mathbf{X}}$ & & & A & & & \\
\hline
\end{tabular}

Figure 4. Nine Party X MP's Completed Ballot Paper.

\begin{tabular}{|c|c|c|c|c|c|c|c|}
\hline \multirow{2}{*}{\multicolumn{2}{|c|}{$\begin{array}{c}\text { THE CABINET } \\
\text { Names of } \\
\text { candidates } \\
\text { in order of preference }\end{array}$}} & \multicolumn{6}{|c|}{$\begin{array}{c}\text { THE } \\
\text { PORTFOLIOS }\end{array}$} \\
\hline & & \multirow{2}{*}{$\begin{array}{l}\sum \\
A\end{array}$} & \multirow{2}{*}{$\begin{array}{l}\sum_{0} \\
\sum_{0} \\
\stackrel{2}{0} \\
0 \\
C\end{array}$} & \multirow{2}{*}{$\begin{array}{l}\text { E् } \\
\text { : } \\
\text { : }\end{array}$} & \multirow{2}{*}{ 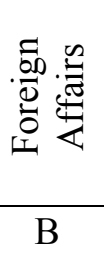 } & \multirow[t]{2}{*}{ 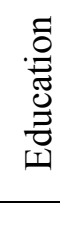 } & \multirow[t]{2}{*}{$\frac{\mathscr{U}}{\mathscr{U}}$} \\
\hline $1^{\text {st }}$ & $\mathbf{M}_{\mathbf{X}}$ & & & & & & \\
\hline $2^{\text {nd }}$ & $\mathbf{N}_{\mathbf{X}}$ & & A & & $\mathrm{C}$ & & $B$ \\
\hline $3^{\text {rd }}$ & $\mathbf{Q}_{\mathbf{Y}}$ & & & B & & A & \\
\hline $4^{\text {th }}$ & $\mathbf{O}_{\mathbf{X}}$ & & & & A & B & \\
\hline $5^{\text {th }}$ & $\mathbf{R}_{\mathbf{Y}}$ & & & & & & $\bar{A}$ \\
\hline $6^{\text {th }}$ & $\mathbf{L}_{\mathbf{W}}$ & & & A & & & \\
\hline
\end{tabular}

Figure 4a. The rebel Party W MP, $\mathrm{P}_{\mathrm{X}}$ 's Completed Ballot Paper.

\begin{tabular}{|c|c|c|c|c|c|c|c|}
\hline \multirow{2}{*}{\multicolumn{2}{|c|}{$\begin{array}{c}\text { THE CABINET } \\
\text { Names of } \\
\text { candidates } \\
\text { in order of preference }\end{array}$}} & \multicolumn{6}{|c|}{$\begin{array}{c}\text { THE } \\
\text { PORTFOLIOS }\end{array}$} \\
\hline & & \multirow{2}{*}{$\begin{array}{l}\sum \\
\mathrm{A}\end{array}$} & \multirow{2}{*}{ 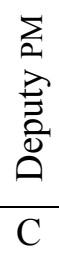 } & \multirow{2}{*}{ 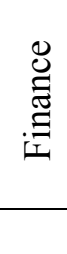 } & \multirow{2}{*}{ 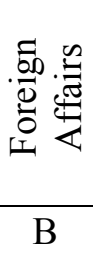 } & \multirow[t]{2}{*}{ 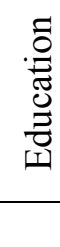 } & \multirow[t]{2}{*}{ 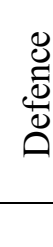 } \\
\hline $1^{\text {st }}$ & $\mathbf{M}_{\mathbf{X}}$ & & & & & & \\
\hline $2^{\text {nd }}$ & $\mathbf{N}_{\mathbf{X}}$ & & & & & & A \\
\hline $3^{\text {rd }}$ & $\mathbf{P}_{\mathbf{X}}$ & & $\mathrm{B}$ & & A & & \\
\hline $4^{\text {th }}$ & $\mathbf{Q}_{\mathbf{Y}}$ & & & & & A & \\
\hline $5^{\text {th }}$ & $\mathbf{R}_{\mathbf{Y}}$ & & A & & & & \\
\hline $6^{\text {th }}$ & $\mathbf{L}_{\mathbf{W}}$ & & & $\mathrm{A}$ & & & \\
\hline
\end{tabular}


Figure 5. A Party Y MP’s Completed Ballot Paper.

\begin{tabular}{|c|c|c|c|c|c|c|c|}
\hline \multirow{2}{*}{\multicolumn{2}{|c|}{$\begin{array}{c}\text { THE CABINET } \\
\text { Names of } \\
\text { candidates } \\
\text { in order of preference }\end{array}$}} & \multicolumn{6}{|c|}{$\begin{array}{c}\text { THE } \\
\text { PORTFOLIOS } \\
\end{array}$} \\
\hline & & \multirow[t]{2}{*}{$\sum_{\Omega}$} & \multirow[t]{2}{*}{ 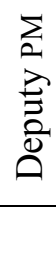 } & \multirow[t]{2}{*}{$\begin{array}{l}\mathscr{O} \\
\stackrel{\Xi}{\Xi} \\
\text { : }\end{array}$} & \multirow[t]{2}{*}{ 怠 } & \multirow{2}{*}{ 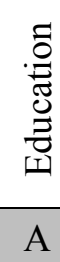 } & \multirow[t]{2}{*}{ 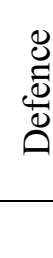 } \\
\hline $1^{\text {st }}$ & $\mathbf{Q}_{\mathbf{Y}}$ & & & & & & \\
\hline $2^{\text {nd }}$ & $\mathbf{M}_{\mathbf{X}}$ & A & $\mathrm{C}$ & & B & & \\
\hline $3^{\text {rd }}$ & $\mathbf{R}_{\mathbf{Y}}$ & & & & & & A \\
\hline $4^{\text {th }}$ & $\mathbf{N}_{\mathbf{X}}$ & & A & & $\mathrm{C}$ & & B \\
\hline $5^{\text {th }}$ & $\mathbf{O}_{\mathbf{X}}$ & & & & A & & B \\
\hline $6^{\text {th }}$ & $\mathbf{L}_{\mathbf{W}}$ & & & A & & & \\
\hline
\end{tabular}

Figure 6. A Party Z MP's Completed Ballot Paper.

\begin{tabular}{|c|c|c|c|c|c|c|c|}
\hline \multirow{2}{*}{\multicolumn{2}{|c|}{$\begin{array}{c}\text { THE CABINET } \\
\text { Names of } \\
\text { candidates } \\
\text { in order of preference }\end{array}$}} & \multicolumn{6}{|c|}{$\begin{array}{c}\text { THE } \\
\text { PORTFOLIOS }\end{array}$} \\
\hline & & \multirow[t]{2}{*}{$\sum$} & \multirow[t]{2}{*}{$\begin{array}{l}\sum \\
\vdots \\
\vdots \\
\vdots \\
0 \\
0\end{array}$} & \multirow{2}{*}{$\begin{array}{l}\underset{\mathscr{E}}{\stackrel{\Xi}{\Xi}} \\
\mathrm{B}\end{array}$} & \multirow[t]{2}{*}{ 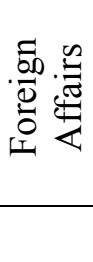 } & \multirow[t]{2}{*}{ 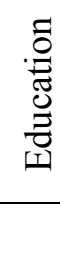 } & \multirow{2}{*}{ 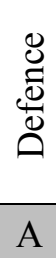 } \\
\hline $1^{\mathrm{st}}$ & $\mathrm{T}_{\mathrm{Z}}$ & & & & & & \\
\hline $2^{\text {nd }}$ & $\mathrm{I}_{\mathrm{W}}$ & A & $\mathrm{C}$ & B & & & \\
\hline $3^{\text {rd }}$ & $\mathrm{J}_{\mathrm{W}}$ & & A & & $\mathrm{C}$ & & B \\
\hline $4^{\text {th }}$ & $\mathrm{K}_{\mathrm{W}}$ & & & A & & B & \\
\hline $5^{\text {th }}$ & $\mathbf{S}_{\mathbf{Y}}$ & & & & & A & \\
\hline $6^{\text {th }}$ & $\mathbf{R}_{\mathbf{Y}}$ & & & & A & & \\
\hline
\end{tabular}

\section{3. The CounT}

To demonstrate how the count would work, let us consider a scenario in which most of the MPs have voted in accordance with their party whips' guidance, as above: nine ballots as per Figure 3 (with just one ballot as in Figure 3a); nine à la Figure 4 (with one as in Figure 4a); five like Figure 5 and five as in Figure 6.

\section{3. 1. The QBS election}

A QBS election is conducted in two parts, each of two stages, and each subsequent stage is used if seats are still to be filled. Any candidates elected in Part I shall not be considered in Part II.

Part I stage (i) all candidates with one quota of $1^{\text {st }}$ preferences are elected; 
both elected;

stage (ii) all pairs of candidates ${ }^{13}$ gaining two quotas of $1^{\text {st }} / 2^{\text {nd }}$ preferences are

Part II stage (iii) popular member any pair of unelected candidates gaining one quota shall have its more elected;

scores only.

stage (iv) all remaining seats shall be awarded on the basis of the candidates MBC

With 30 voters electing 6 representatives, the quota is the integer above $(30 / 7)=5$. The first steps are to see who has support for which posts, who has what MBC totals, and which singletons/pairs have achieved 1/2 quotas of top preferences; the first set of results is in Figure 7. Initially, in the matrix, only the As are of interest, so these are shown in tint.

With nine party $\mathbf{W}$ MPs casting full ballots give $\mathbf{I}_{\mathbf{W}}$ a first preference and then an A for the post of PM, as in Figure $3, \mathbf{I}_{\mathbf{W}}$ gets $(9 \times 6=) 54 \mathrm{~A}$ points for that portfolio. When one further voter gives her a $2^{\text {nd }}$ preference, she gets another $5 \mathrm{~A}$ points. And when five Party $\mathrm{Z}$ MPs also give her a second preference, she gets a further $25 \mathrm{~A}$ points. And so on, for all of Figure 7.

Figure 7. The Initial Results.

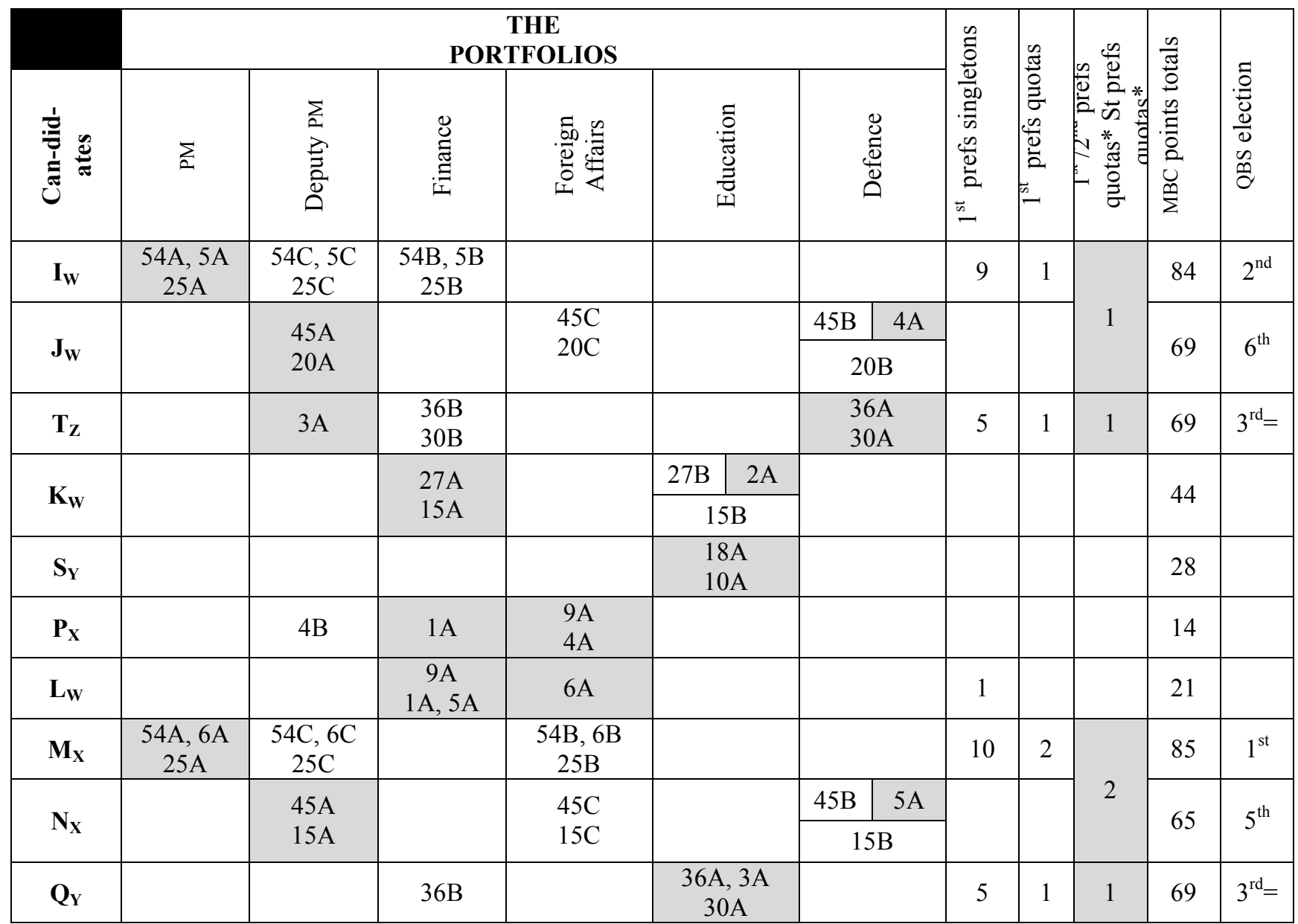

13 If $x$ voters give their $1^{\text {st }}$ and $2^{\text {nd }}$ preferences to candidates $\mathbf{M}_{\mathbf{X}}$ and $\mathbf{N}_{\mathbf{X}}$, if $y$ voters give their $1^{\text {st }}$ and $2^{\text {nd }}$ preferences to candidates $\mathbf{N}_{\mathbf{X}}$ and $\mathbf{M}_{\mathbf{X}}$, and if $x+y \geq 1$ quota, then the $\mathbf{M}_{\mathbf{X}} / \mathbf{N}_{\mathbf{X}}$ pair is said to have 1 quota. 


\begin{tabular}{|c|c|c|c|c|c|c|c|c|c|c|c|}
\hline $\mathbf{O}_{\mathbf{X}}$ & & & & $\begin{array}{c}27 \mathrm{~A} \\
10 \mathrm{~A}\end{array}$ & $27 \mathrm{~B}$ & $10 \mathrm{~B}$ & & & 37 & \\
\hline $\mathbf{R}_{\mathbf{Y}}$ & & $2 \mathrm{~A}$ & & $5 \mathrm{~A}$ & & $\begin{array}{c}18 \mathrm{~A} \\
20 \mathrm{~A}\end{array}$ & & & & 45 & \\
\hline $\begin{array}{c}\text { Points } \\
\text { cast }\end{array}$ & 169 & 130 & 58 & 61 & 99 & 113 & & & & 630 & \\
\hline
\end{tabular}

* The $\mathbf{M}_{\mathbf{X}} / \mathbf{N}_{\mathbf{X}}$ pair have two quotas and the $\mathbf{I}_{\mathbf{W}} / \mathbf{J}_{\mathbf{W}}$ pair have one quota.

$+\quad$ Each ballot consists of 21 points; the number of MPs is 30 ; so the total number of points cast is $21 \times 30$

$=630$

From the information shown, the cabinet may be elected, as in Figure 8.

Part I stage (i) elects $\mathbf{M}_{\mathbf{X}}, \mathbf{I}_{\mathbf{W}}, \mathbf{T}_{\mathbf{Z}}$ and $\mathbf{Q}_{\mathbf{Y}}$;

stage (ii) the $\mathbf{M}_{\mathbf{X}} / \mathbf{N}_{\mathbf{X}}$ pair has two quotas; $\mathbf{M}_{\mathbf{X}}$ was elected in stage (i); so this stage (ii) elects

$\mathbf{N}_{\mathbf{X}}$

Part II stage (iii) there are no pairs of unelected candidates gaining a quota.

stage (iv) the remaining seat goes to the unelected candidate with the highest MBC total, $\mathbf{J}_{\mathbf{W}}$.

The QBS election is now complete. Please note that popularity as per the QBS election does not necessarily coincide with the MBC social ranking.

Figure 8. The Cabinet Election, initial results.

\begin{tabular}{|c|c|c|c|c|c|c|c|c|}
\hline 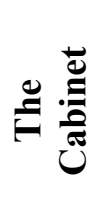 & $\sum$ & 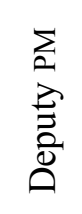 & $\begin{array}{l}\stackrel{\Xi}{E} \\
\stackrel{\Xi}{\Xi} \\
\text { 芒 }\end{array}$ & 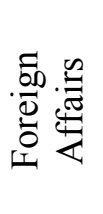 & 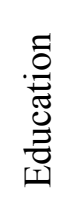 & 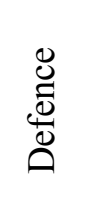 & 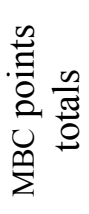 & 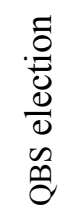 \\
\hline $\mathbf{M}_{\mathbf{X}}$ & $85 \mathrm{~A}$ & $85 \mathrm{~B}$ & & $85 \mathrm{C}$ & & & 85 & $1^{\mathrm{st}}$ \\
\hline $\mathbf{I}_{\mathbf{W}}$ & $84 \mathrm{~A}$ & $84 \mathrm{~B}$ & $84 \mathrm{C}$ & & & & 84 & $2^{\text {nd }}$ \\
\hline $\mathbf{Q}_{\mathbf{Y}}$ & & & $36 \mathrm{~B}$ & & $69 \mathrm{~A}$ & & 69 & $3^{\text {rd }}=$ \\
\hline $\mathbf{T}_{\mathbf{Z}}$ & & $3 \mathrm{~A}$ & $66 \mathrm{~B}$ & & & $66 \mathrm{~A}$ & 69 & $3^{\text {rd }}=$ \\
\hline \multirow{2}{*}{$\mathbf{N}_{\mathbf{X}}$} & & \multirow{2}{*}{$60 \mathrm{~A}$} & & \multirow{2}{*}{$60 \mathrm{C}$} & & $5 \mathrm{~A}$ & \multirow{2}{*}{65} & \multirow{2}{*}{$5^{\text {th }}$} \\
\hline & & & & & & $60 \mathrm{~B}$ & & \\
\hline \multirow{2}{*}{$\mathbf{J}_{\mathbf{W}}$} & & \multirow{2}{*}{$65 \mathrm{~A}$} & & \multirow{2}{*}{$65 C$} & & $4 \mathrm{~A}$ & \multirow{2}{*}{69} & \multirow{2}{*}{$6^{\text {th }}$} \\
\hline & & & & & & $65 B$ & & \\
\hline
\end{tabular}

\section{3. 2. The MBC election}

To proceed to the appointment of the various successful candidates, consideration is focussed on the individual A sums achieved by each of the six candidates for each of the various posts, and these are considered in descending order, starting with the highest, 85A shown in Figure 8 in dark tint. This sum means $\mathbf{M}_{\mathbf{X}}$ becomes the PM, so the B and C sums for $\mathbf{M}_{\mathbf{X}}$ are no longer required, and may be erased. The appointment of $\mathbf{M}_{\mathbf{X}}$ also means that $\mathbf{I}_{\mathbf{W}}$ cannot be PM, so her As are transferred to Bs, as shown in lighter tint. The next highest sum is this 84 , so $\mathbf{I}_{\mathbf{W}}$ becomes Deputy PM. Meanwhile, the A sums listed in the Deputy PM column may be transferred, as per their voters' wishes, into their B sums. Hence Figure 9. 
Figure 9. The Cabinet Election, interim results.

\begin{tabular}{|c|c|c|c|c|c|c|c|c|}
\hline 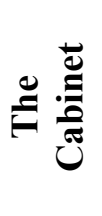 & $\sum$ & $\begin{array}{l}\sum_{1} \\
\text { 至 } \\
\overline{0} \\
0\end{array}$ & 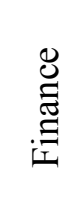 & 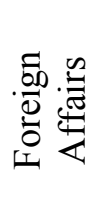 & 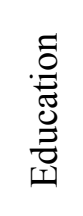 & $\frac{8}{\mathscr{E}}$ & 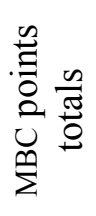 & 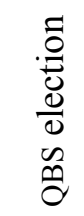 \\
\hline $\mathbf{M}_{\mathbf{X}}$ & $85 \mathrm{~A}$ & & & & & & 85 & $1^{\mathrm{st}}$ \\
\hline $\mathbf{I}_{\mathbf{W}}$ & & $84 \mathrm{~B}$ & & & & & 84 & $2^{\text {nd }}$ \\
\hline $\mathbf{Q}_{\mathbf{Y}}$ & & & $36 \mathrm{~B}$ & & $69 \mathrm{~A}$ & & 69 & $3^{\mathrm{rd}}=$ \\
\hline $\mathbf{T}_{\mathbf{Z}}$ & & & $66 \mathrm{~B}$ & & & $66 \mathrm{~A}$ & 69 & $3^{\text {rd }}=$ \\
\hline $\mathbf{N}_{\mathbf{X}}$ & & & & $60 C$ & & $\begin{array}{c}5 \mathrm{~A}+60 \mathrm{~B} \\
=65\end{array}$ & 65 & $5^{\text {th }}$ \\
\hline $\mathbf{J}_{\mathbf{W}}$ & & & & $65 \mathrm{C}$ & & $\begin{array}{c}4 \mathrm{~A}+65 \mathrm{~B} \\
=69\end{array}$ & 69 & $6^{\text {th }}$ \\
\hline
\end{tabular}

The next highest sum in 69, of which there are two; the tie, however, is not contentious. 69A gives $\mathbf{Q}_{\mathbf{Y}}$ Education, while another 69 means $\mathbf{J}_{\mathbf{W}}$ looks after Defence. The next highest sum is 66 , which appoints $\mathbf{T}_{\mathbf{Z}}$ to Finance, and finally, 60 puts $\mathbf{N}_{\mathbf{X}}$ into Foreign Affairs. So Figure 10 is the outcome.

Figure 10. The Cabinet Election, the outcome.

\begin{tabular}{|c|c|c|c|c|c|c|c|c|}
\hline 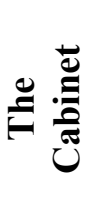 & $\sum$ & 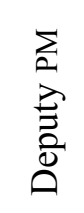 & 芑 & 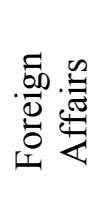 & 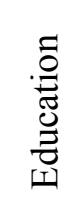 & $\frac{8}{0}$ & 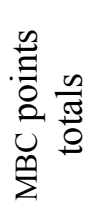 & $\begin{array}{l}\frac{0}{0} \\
000 \\
0 \\
0 \\
0 \\
0 \\
0\end{array}$ \\
\hline $\mathbf{M}_{\mathbf{X}}$ & $85 \mathrm{~A}$ & & & & & & 85 & $1^{\mathrm{st}}$ \\
\hline $\mathbf{I}_{\mathbf{W}}$ & & $84 \mathrm{~B}$ & & & & & 84 & $2^{\text {nd }}$ \\
\hline $\mathbf{Q}_{\mathbf{Y}}$ & & & & & $69 \mathrm{~A}$ & & 69 & $3^{\mathrm{rd}}=$ \\
\hline $\mathbf{T}_{\mathbf{Z}}$ & & & $66 \mathrm{~B}$ & & & & 69 & $3^{\text {rd }}=$ \\
\hline $\mathbf{N}_{\mathbf{X}}$ & & & & $60 C$ & & & 65 & $5^{\text {th }}$ \\
\hline $\mathbf{J}_{\mathbf{W}}$ & & & & & & 69 & 69 & $6^{\text {th }}$ \\
\hline
\end{tabular}

If there were a tie in any of the sums, priority would be given to the more popular candidate as measured by the QBS election and, if still tied, by their MBC totals; and if both sums and totals are equal, by the number of points cast for the various portfolios, as measured in the bottom 'Points cast' row of Figure 7. 


\section{4. The Final Result}

Because nearly every MP voted as per the whips' directives, this cabinet does indeed consist of 2, 2, 1 and 1 ministers for parties $\mathbf{W}, \mathbf{X}, \mathbf{Y}$ and $\mathbf{Z}$ respectively. In a cabinet which is not a multiple of 6 members, proportionality will not, of course, be so exact.

\section{5. An Analysis}

In this hypothetical example, the two opposing blocs - parties $\mathbf{W}$ and $\mathbf{Z}$ on the one hand, with $\mathbf{X}$ and $\mathbf{Y}$ on the other - were equally matched. Both sides knew they could not win every post, so $\mathbf{W}$ and $\mathbf{Z}$ did not go for Foreign Affairs, while the $\mathbf{X} / \mathbf{Y}$ team chose not to contest Finance. Both sides, however, competed for the premiership, which $\mathbf{M}_{\mathbf{X}}$ won by a whisker. Her margin of victory could have been even greater, if she had managed to persuade all her $\mathbf{Y}$ party colleagues to give her a first preference. There again, if parties $\mathbf{W}$ and $\mathbf{Z}$ had concentrated their efforts in a similar way, then maybe $\mathbf{I}_{\mathbf{W}}$ could have won. In real life, of course, while their top preferences might be identical, their MBC scores are almost bound to be different, if only because of the preferences of MPs in minority parties.

It is easy enough for a party, which knows it has a quota, to guarantee itself a cabinet post. What is definitely not so easy is for that party to secure its desired ministry. Which means, of course, its fortunes would be enhanced by pre-election agreements with other parties, and this, it is argued, is a further necessary pre-requisite of a successful power-sharing administration.

Party $\mathbf{W}$ can feel fairly satisfied, for its top two candidates both got elected to cabinet, although doubtless $\mathbf{I}_{\mathbf{W}}$ was disappointed not to get the premiership. Party $\mathbf{X}$ is well content, as too is party $\mathbf{Y}$; and even $\mathbf{Z}$ has little cause to complain. On balance, the $\mathbf{X} / \mathbf{Y}$ team voted in a more unified way, but when all concerned understand the methodology, the win-win nature of this voting procedure will be even more apparent.

As noted in para 4.3.1, all the candidates were elected on the basis of their top preferences. In real life, and especially in a parliament of many parties, it may be expected that quite a few of the successful cabinet members will be elected on the basis of their MBC totals, i.e., on the basis of their cross-party support. It is in the hope of gaining that extra seat that most political parties, forever ambitious and over-confident, will tend to nominate rather more candidates than perhaps they should: in the above example, 3, 3, 2 and 2 rather than 2, 2, 1 and 1, (para 4).

\section{WILL IT WORK?}

If people take decisions by majority vote, then, like night follows day, like the English House of Commons, the American Congress and now too the Russian Duma, they will split into opposing camps. If, however, they use the $\mathrm{MBC}$, a different psychology pertains.

It works like this. In a vote on $n$ options, a voter may submit $m$ preferences, where $n \geq$ $m \geq 1$; points are awarded to $\left(1^{\text {st }}, 2^{\text {nd }} \ldots m^{\text {th }}\right)$ preferences according to the rule $(m, m-1 \ldots l) .^{1 \overline{4}}$ So, if someone submits a full ballot in a 6-option ballot, then her $1^{\text {st }}$ preference gets 6 points, her $2^{\text {nd }}$ gets 5 , and so on. If another submits only a partial ballot of two options, then his $1^{\text {st }}$ preference gets 2 points, his $2^{\text {nd }}$ gets 1 point. In effect, she who participates fully in the democratic process has a full influence on the outcome; he who submits only a partial role has

14 This rule is in fact closer to that which was first proposed by Jean-Charles de Borda than that which has come to be called the Borda count (BC). (18 and 19). 
a partial influence; and she who abstains has no influence at all. In other words, the voter is incentivised to submit a full ballot. This means, of course, that he supports his own favourite, but he also, as it were, recognises the validity of other options and thus shows mutual respect to other participants.

Meanwhile, consider the protagonist. She knows that, to win, her option must get lots of high preferences, some middle ones perhaps, and very few low ones. It is worth her while, therefore, to engage in dialogue with her erstwhile, majoritarian opponents.

A cabinet can best work together if it works in consensus, in a procedure which is either entirely verbal or also involves an MBC vote. Likewise, (I) a political party would be well advised, if and when it is debating a matter of great controversy, not to use a majority vote (and risk splitting the party into two factions or wings); (II) a coalition of two or more parties, when coming to a joint policy or whatever, should also aim to do so in consensus; and (III) a power-sharing parliament and government should likewise aim to resolve contentious matters by MBC.

As noted earlier, the matrix vote is based on an MBC. It therefore encourages the individual MP to cast a full slate of preferences. Furthermore, because the methodology is proportional, he will know that in the given example, party $\mathbf{W}$ can expect to win 2 or at the most 3 seats. In which case, having cast his top two or three preferences for party colleagues, he might as well use his lower preferences to support any suitable candidates from other parties. In other words, the matrix vote will inherently encourage inter-party dialogue - or maybe 'polylogue' would be a better word.

$* * * * *$

Majoritarian politics works on the basis of the whip. When there is a choice of only two options on the order paper, it is usually easy enough for the party leadership to persuade any colleagues to support one option, given that any other course of action would help the opposition party. In an MBC of, let us say, six options, however, there are in fact 720 different ways of submitting a full ballot. Using a more plural voting procedure will thus make it much more difficult for the whip to advocate only one course of action, and the MBC could lead to many more votes being free. In effect, parliament will be more difficult to control and, in the long run, the $\mathrm{MBC}$ might facilitate the restoration of that democratic ideal which declares parliament to be sovereign; after all, the executive should be little more than the word implies, the means by which the will of parliament is executed.

The choice involved in a matrix vote is even greater. In the above example of 30 MPs voting in a cabinet of 6 ministers, each voting MP has a choice of over 300 million different ways of casting her As. That's pluralism. In such a situation, it would be almost impossible for the party leaders to control all of its MPs. Just as in Northern Ireland with the relatively simple d'Hondt process, 'departmental allocations were agreed in advance,' (20), it is suggested that the introduction of a matrix vote would facilitate even more inter-party discussions and agreements.

An all-party power-sharing form of governance could work, therefore, and could well work successfully, if:

(a) all non-urgent decisions were taken in consensus, either verbally and/or via a preference MBC vote; and

(b) the principle of collective responsibility were shared by the entire parliament.

MPs would still have their differences, of course, and these would be reflected in Hansard in the way they cast their preferences. If the mood of the country changed, then, 
when the time came for the next election, a new House should reflect that change with, if the electoral system were fair and proportional, a good degree of accuracy. A two per cent swing in the will of the people should correspond to a similar shift, not only in parliament but also in government.

\section{CONCLUSION}

The democratic process should be the means by which problems are resolved peacefully. Sadly, democracy has evolved into a very adversarial form and, in many circumstances, the exercise of such a win-or-lose election (Kenya) or referendum (Bosnia) has been used as a provocation for violence. In contrast, the three voting procedures mentioned in this article the MBC, QBS and the matrix vote - could be the very catalysts of a consensus which is so necessary (a) in countries now confronted by some of the biggest financial crises ever seen, (b) in so many conflict zones and plural societies generally, and too (c) in international forums on matters of profound importance to the very survival of our species. Questions on complex matters like climate change cannot best be resolved by majority votes. Consensus voting, on the other hand, could help to create that milieu in which inclusive collective decision-making comes to be the norm.

\section{ACKNOWLEDGEMENTS}

The matrix vote was invented by the author in 1978. It is based on two Borda voting methodologies: the Borda count, (BC), advocated by Nicholas Cusanus in 1435 and in 1784 by Jean-Charles de Borda; and the quota Borda system, (QBS), devised by the late Sir Michael Dummett.

This tabular methodology was first put to the test in a public meeting in Belfast in 1986 under the auspices of the New Ireland Group (NIG). Over 200 persons were present, political and apolitical, public and professional, priest and paramilitary; the politicians ranged from members of the Official (now Ulster) Unionist Party to others from Sinn Féin. Such a cross-community gathering still eight years before the ceasefire was unique, but that was not the only achievement: firstly, with the aid of a Borda count, the participants' consensus was identified; and secondly, a matrix vote was used to show how a power-sharing administration could be elected.

Both voting mechanisms have often been used since, by the NIG and, North and South, by the Irish Green Party. In addition, the matrix vote was tested at two public meetings in Dublin in 2009 and 2012. Thanks are due to all who have participated in these various meetings.

\section{BIOGRAPHY}

Peter Emerson first gained a degree equivalent and then served in the British navy in submarines, mainly in the Far East. Having seen much of the poverty which (still) haunts this world, however, he resigned his commission and worked, instead, as a volunteer teacher in a school for the poor in Kenya. Four years later, in 1975, this child of an Irish Protestant father and an English Catholic mother moved to Belfast, where he soon became a peace activist, promoting inclusive voting procedures and bringing the two sides together in consensus experiments.

As a direct result of this work, he campaigned against all forms of violence, including the nuclear bomb. Thus, in 1984, he chose to visit the Soviet Union. Four years later, with perestroika well underway, he published articles on democratisation in Moscow News and Novy Mir (Новый Mup).

In 1997, he and a few colleagues set up the de Borda Institute. As the director, he has lectured on power-sharing in Europe, Africa, the Americas, and most recently China. His latest work is Defining Democracy (Springer, 2012). He speaks Russian, some Serbo-Croat and Swahili, and is now learning Mandarin Chinese. 


\section{References}

[1] Churchill W. S. (1956). A History of the English-speaking Peoples. Cassell, London. Book II, 294.

[2] Bogdanor V. (1981). The People and the Party System. Cambridge University Press, Cambridge. 113.

[3] Lijphart A. (1995). Electoral Systems and Party Systems. Oxford University Press, Oxford. 17.

[4] Gorbachev M. (1987). Perestroika. Collins, London. 216.

[5] Havel V. (1989). Open Letters, Faber and Faber. London and Boston. 25.

[6] Kapuściński R. (2002). The Shadow of the Sun. Penguin, London. 315.

[7] Mandela N. (1999). Long Walk to Freedom. Abacus, London. 25.

[8] Legum C., Mmari G. (1995). (eds) Mwalimu - The Influence of Nyerere. BritainTanzania Society, London. 64.

[9] Museveni Y. K. (1997). Sowing the Mustard Seed. Macmillan, London. 16.

[10] Kadima D. (2006). The Politics of Party Coalitions in Africa. EISA, South Africa. 27.

[11] Glenny M. (1996). The Fall of Yugoslavia. Penguin, London. 148.

[12] Taylor R. (2009). The injustice of a consociational solution to the Northern Ireland problem. In Consociational Theory. Taylor R. (ed). Routledge, Abingdon.

[13] Dummett M. (1984). Voting Procedures. oup, Oxford. 7.

[14] Othieno T. (2006). Democracy and Security in East Africa. In Matlosa K, Elklit J and Chiroro B. (eds) Challenges of Conflict, Democracy and Development in Africa, EISA, South Africa. 281.

[15] Lijphart A. (2012). Patterns of Democracy. $2^{\text {nd }}$ edition. Yale University Press, New Haven and London. 6.

[16] Prunier G. (1995). The Rwanda Crisis. Hurst and Co., London. 183.

[17] Emerson P. (2012). Defining Democracy. Springer, Heidelberg. 143-50.

[18] Saari D. G. (2008). Disposing Dictators, Demystifying Voting Paradoxes. Cambridge University Press, Cambridge. 197.

[19] Emerson P. (2013). The original Borda count and partial voting. In Social Choice and Welfare, Vol. 40, № 2, 353-8.

[20] Wilford R. (2009). Consociational Government. In Taylor R. (ed) (2009) Consociational Theory. Routledge, Abingdon. 186. 